\title{
Merchantability and assortment structure of pine stands affected by root rot in the Volyn Polissya region, Ukraine
}

\author{
Sergiy Musienko ${ }^{1}$, Volodymyr Luk'yanets ${ }^{2}$, Oksana Tarnopylska ${ }^{1,2 *}$, \\ Oleksii Kobets $^{2}$, Vira Babenko ${ }^{1}$ \\ ${ }^{1}$ O. M. Beketov National University of Urban Economy in Kharkiv, 17, Marshal Bazhanov Street, Kharkiv, 61002, Ukraine \\ ${ }^{2}$ Ukrainian Research Institute of Forestry and Forest Melioration named after G. M. Vysotsky 86 Pushkinska St., \\ 61024, Kharkiv, Ukraine
}

\begin{abstract}
The study was conducted in the forests of the State Enterprise "Gorodotske Forest Economy", located in the Manevytsko-Volodymyretsky region of the Volyn Polissya in Ukraine. The annosum root rot (Heterobasidion annosum (Fr.) Bref.) impact on timber merchantability was investigated. The comparison of the cost estimation of stands assortment structure was carried out on the basis of the market value at current selling prices of the State Enterprise "Gorodotske Forest Economy" of the Volyn Regional Department of Forestry and Hunting as of 2017, taking into account the quality and the average length of the assortments. We present a comparative analysis of productivity, merchantability and assortment structure and financial value of timber volume by various assortments of pine and birch stands of the Volyn Polissya region affected by annosum root rot. We found that in the pine plantations, the overall productivity and the value of merchantable wood was higher by $42 \%$ in the control sites (areas between the fungal disease centers) as compared with those in the root rot disease centers. In the middle-aged birch-pine stands, the value of merchantable wood was higher than that in pine plantations of 34 the comparable age: by $9 \%$ in the disease centers and by $8 \%$ in control sites.
\end{abstract}

Key words: artificial pine stands; annosum root rot; disease center; merchantability; assortment structure; assortment value

Editor: Tomáš Hlásny

\section{Introduction}

One of important questions in forestry, concerning growing of high-yield pine stands, is a problem of root rot that is still current, as there is no efficient methods of the disease control. Scots pine (Pinus sylvestris L.) is most severely affected by root rot caused by the fungus Heterobasidion annosum (Fr.) Bref. Due to the disease globalization in the last decades, it covers all countries of Europe (CMI 1980; EPPO 2014; Vasiliauskas et al. 2002), North America (Harrington et al. 1989), Central America and Caribbean (USDA Forest Service 2002; EPPO 2014), some regions of Australia (EPPO 2014), Asia (Parmasto 1986), and Africa (Morocco) (EPPO 2014). The problem of disease appearance and spreading in Ukraine arose up in a middle of the $20^{\text {th }}$ century as pine forest plantations were established in considerable areas of abandoned arable lands, pastures, and wastelands, where soils had lost forest properties (EPPO 2014). The root rot reduces the productivity of forest stands, causes their early deterioration, initiates the massive propagation of pests, increases the fire hazard, causes sanitation felling, worsens the soil-protective, water-conservation and sanitary functions of a forest, and, in general, significantly reduces a growing stock and affects the assortment structure of pine forests in Ukraine (Ladeyshchikova etal. 2001). The fungus causes a mottled rot in the lower part of the trunk, the length of which along the trunk can reach $6-8 \mathrm{~m}$ that leads to timber loss, which amounts $50 \%$ (Onyskiv \& Kidyk 2008; Churakov et al. 2013; Lapitan et al. 2013).

Besides decreased profits due to reduced timber yield and deterioration in the quality, annosum root rot causes the stand increment loss (Bazzigher \& Schmid 1969; Jambunathan et al. 1986; Vollbrecht et al. 1994; Brandtberg et al. 1996; Khun et al. 2011). It deteriorates the trunk form due to the thickening the lower part of the trunk (Bazzigher \& Schmid 1969; Vollbrecht et al. 1994; Khun 
et al. 2011). However, the loss of increment of living trees affected by annosum root rot is not often taken into account in forest management planning. For example, the growing stock increment of affected trees decreases on $10 \%$ during a 5 -year period as compared to healthy trees. For a longer period, the increment losses can be considerably perceptible in certain stands (Jambunathan et al. 1986). The trees affected by root rots are sensitive to wind damage (Yde-Andersen 1970; Semenkova 1971; Bendz-Hellgren et al. 1999) and to the attacks of bark beetles Dendroctonus micans (Froelich et al. 1978; Rasanen et al. 1985) as well.

The use of control methods to decrease the rates of the disease requires investments. Additional costs are needed for forest harvesting in a summer period for protecting measures to prevent the infection of stump surface in summer. Most of the forestry measures, in particular, lowering the felling age, controlled burning-out, grubbing and change of wood species - are also expensive. The efficiency of these measures is difficult to be foreseen because of the absence of long-term experience with the measures.

In Ukraine, annosum root rot is most prevalent in young and middle-aged pine plantations established on lands after agricultural use in Polissya, Carpathian parts and some areas of the Forest-Steppe. Considering the fact that a significant part of such lands falls on Volyn Polissya, the study of pine forests decline on former arable lands is now becoming increasingly relevant. The influence of annosum root rot on pine stands was investigated in the studies of Vedmid et al. (2013), Lapitan et al. (2013) and Mihaylichenko et al. (2014).

In Ukraine, predominantly pure pine plantations are created again on cutting areas affected by annosum root rot. According to Ladeyshchikova et al. (2001), the establishment of birch (Betulapendula Roth.) plantations as a pine forecrop is proposed in fresh and moist fairly infertile pine site types on the formerly arable lands in order to reduce the infectious background of the root rot and contribute to the formation of the soil microbiota natural composition. However, this provision needs to be confirmed, as there is not enough data on the growth, health condition, productivity, merchantability, and assortment structure of birch plantations on the post-agricultural lands. In Finland, birch trees appeared to be very resistant to $H$. annosum s. str. Obviously, $H$. annosum s. str. needs pine or spruce trees as a food supply to allow for infesting living birch trees (Rasanen et al. 1985).

The aim of the study was to compare the productivity, merchantability, assortment structure and value of timber volume by different types of assortments of pine stands affected by annosum root rot for trees growing in the root rot disease centers and for trees growing between the centers in the Volyn Polissya zone. Also, the aim of the study was to compare the above mentioned values for infected pine stands and for healthy birch stands in the same forest site conditions for possible substitution of pine stands by more root rot resistant birch plantations.

\section{Material and methods}

The study was conducted in pine forests of the State Enterprise "Gorodotske Forest Economy"; the enterprise is in a jurisdiction of State Forest Resources Agency of Ukraine and is located in Volyn Polissya of Ukraine. The climate of the region is moderate continental with mild winter and warm summer. The average temperature is $-4.7^{\circ} \mathrm{C}$ in January and $+18.5^{\circ} \mathrm{C}$ in July. The absolute minimum is $-39^{\circ} \mathrm{C}$, the absolute maximum is $+39^{\circ} \mathrm{C}$. The period with a temperature above $+10^{\circ} \mathrm{C}$ is $150-160$ days. The sum of active temperatures for this period is $2,495-2,580^{\circ}$. Precipitations are $550-640 \mathrm{~mm}$ per a year; most of them come in summer, the least in winter.

The Volyn Polissya zone has widely occurring glacial and karst forms of relief and valley landscapes. The zone is characterized by excessive moistening and development of the water-logged lands and bogs; there are numerous (over 200) lakes and large forested areas. The bottom-lands of mixed forests zone (45\%), meadowbog landscapes (about 10\%) and moraine-frontal plains are prevailing here, in particular, the Volyn range. Among pre-Quaternary deposits, cretaceous rocks are prevailing, which determine the development of karst forms of relief: lake basins, karst funnels, and humus-carbonate soil formation (Marinich et al. 1985).

The total area of forests of Volyn Polissya is over 2,300 thousand ha. The area of forest plots covered with forest vegetation in the State Enterprise "Gorodotske Forest Economy" is $28,240.5$ ha. Scots pine is the main forest forming tree species; it occupies near $68 \%$ of the area covered with forest vegetation (Source: Production Association "Ukrderzhlisproekt").

To evaluate the merchantability and assortment structure of middle-aged artificial pine plantations affected by annosum root rot, 9 sample plots were established in the stands, containing infected and dead trees (disease centers); the stands were at age of 51,61 and 75 years. Additional 9 sample plots were established as a control in a relatively healthy part (i. e. without evidence of deterioration) of these stands (the area between the disease centers) (Fig. 1).

The number of replications is three for each of three age classes (with an interval of 10 years).

Pure birch stands are resistant against annosum root rot. From this view, one sample plot was laid out on abandoned arable lands in the 51-year-old undamaged birch stand (Fig. 2) to compare health, growth and productivity characteristics with that of diseased pine stands.

For birch and pine stands affected by the root rot, assortment structure was compared and a value of timber was assessed.

The area of sample plots is 0.5 ha on average and the number of the dominant trees is above 200 trees on each plot (Anuchin 1982). The root rot disease center is an area occupied by a group of declining (severely weakened) and dying trees including clearings resulting from sanitary 

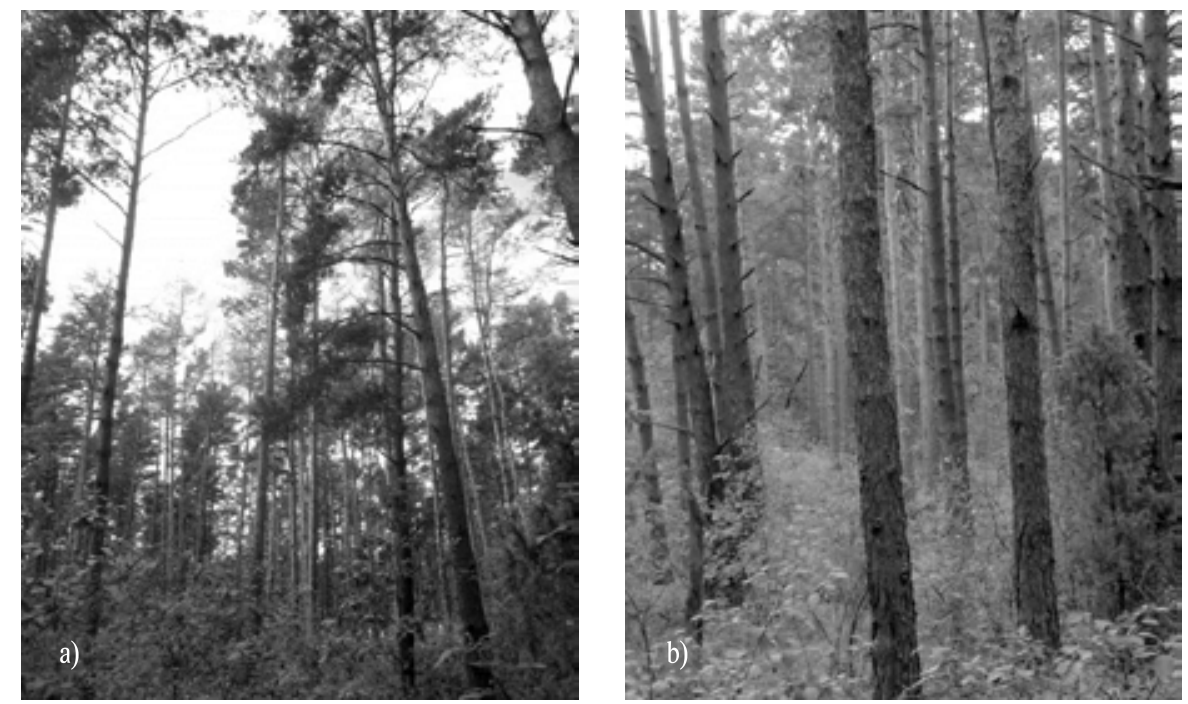

Fig. 1. 75-year-old pine plantation: $a$ - in annosum root rot disease center; $b$-in the area between the disease centers (control).

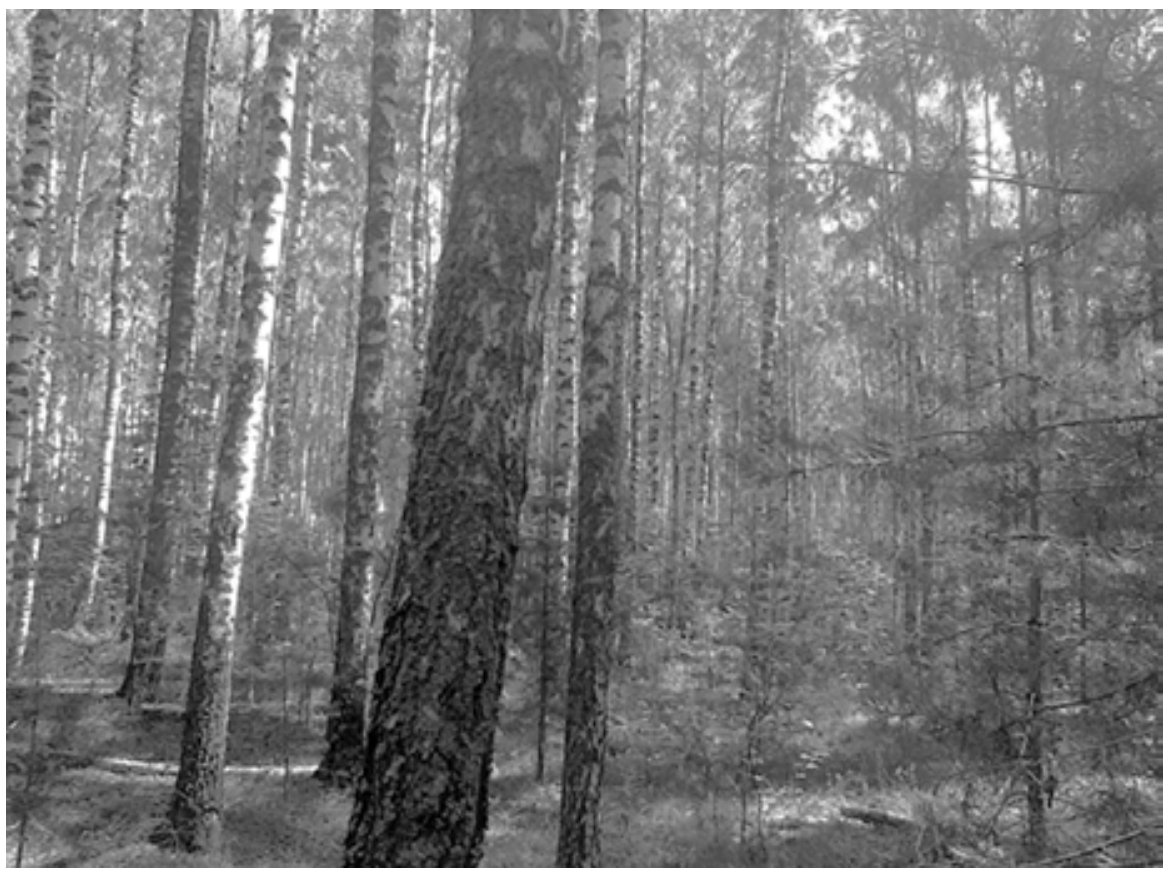

Fig. 2. 51-year-old birch plantations.

cutting of the trees affected by annosum root rot. The area between the disease centers is a viable part of the stand, not disordered by the pathogenic loss of growing trees. The disease-produced loss of forest comprises very weakened and dying trees and fresh and old standing dead trees.

Enumeration survey (including breast height diameter and tree height mensuration) was performed in all sample plots by 4-cm categories based on DBH (8-12-16 $-20 \mathrm{~cm}$ etc.; Anuchin 1982). The trees were grouped into three categories according to the merchantability, as follows: merchantable trees - the total length of merchantable part at the bottom of the trunk is $6.5 \mathrm{~m}$ and longer, semi-merchantable trees - the length of merchantable part at the bottom of the trunk is from 2 to $6.5 \mathrm{~m}$, fuelwood trees - the length of merchantable part at the bottom of the trunk is less than $2 \mathrm{~m}$.

The health condition of trees was estimated using 6 categories as follows: I - trees without evidence of decline, II - weakened trees, III - severely weakened trees, IV - dying trees, $\mathrm{V}$ - standing dead trees died over the presentyear, VI-standing dead trees died over recent years (Sanitary Forests Regulations 2016). The degree of stand damage is characterized by health indicator, which was calculated using the formula [1]: 


$$
I_{c}=\frac{K_{1} n_{1}+K_{2} n_{2}+\cdots+K_{6} n_{6}}{N}
$$

where: $I_{c}$ - health indicator of the stand; $K_{1}, \ldots, K_{6}$ - category of the health condition of the trees (from I to VI) $; n_{1}, \ldots, n_{6}-$ the number of trees of given category of the health condition; $N$ the total number of trees on the sample plot.

The trunks of merchantable trees are divided into three dimensional and qualitative categories, depending on the diameter of the trunk segment in the upper section without bark: large-sized $-25 \mathrm{~cm}$ or more, mediumsized - from 14 to $24 \mathrm{~cm}$, and small-sized - from 6 to $13 \mathrm{~cm}$. Round merchantable timber logs were grouped into assortments according to their intended purpose: building timber, which is used for wooden shipbuilding, piles, bridges, poles of aerial lines of communication; saw logs, which are the raw materials for lumber production; mine timber, which is the timber for excavation support; pulpwood, which is assortment for the production of cellulose and wood pulp; veneer logs used for veneer production, which is then used in plywood, furniture and other industries.

Absolute and relative stand density was determined by using the tables according to Shvydenko et al. (1987). The total stock volume per hectare was estimated according to the tables of Nikitin (1984) and Strochinsky et al. (2007a, b) for young and middle-aged stands cruising.

Merchantability of the stands was estimated by the ratio of merchantable and fuelwood trunks and by the subsequent division of the stock into qualitative and quantitative categories (timber by size categories and grades, industrial raw materials, fuelwood, waste) (Nikitin 1984). The merchantability was estimated by the forest mensuration results, using assortment tables, which are used during the inventory evaluation of the felling areas (Nikitin 1984).

The comparison of cost estimations of the stands assortment structure was carried out on the basis of the economic benefit that can be obtained from the sale of the timber at current selling prices (Pearse 1990; Syn- yakevych 1996). The prices correspond to the average selling prices of the State Enterprise "Gorodotske Forest Economy” of Volyn Regional Department of Forestry and Hunting as of 2017, taking into account the quality and the average length of the assortments.

Merchantability of a stand is attributable mainly to the patterns of distribution of the number of trunks by thickness grades, depending on the average diameter of the tree stand. Therefore, the non-parametric KolmogorovSmirnov goodness-of-fit test ( $\lambda$ ) (Massey 1951) was used during the studies of the merchantability of the stands. For this purpose, two series of empirical distributions of tree diameters in paired sample plots (in the root rot disease centers and in the areas between the disease centers (the control) laid out in pine plantations affected by annosum root rot were compared and their belonging to one general population was assessed according to the formula [2]:

$$
\lambda=d_{\max } \sqrt{\frac{n_{1} \cdot n_{2}}{n_{1}+n_{2}}}
$$

where: $d_{\max }$-the maximum difference between the values of the first and second series of cumulative frequencies; $n_{1}, n_{2}$ - the sums of all variants of the population.

In this case,

$$
d_{\max }=\sqrt{\frac{p_{1}}{n_{1}}}-\sqrt{\frac{p_{2}}{n_{2}}}
$$

where: $\sqrt{\frac{p_{1}}{n_{1}}}$ and $\sqrt{\frac{p_{2}}{n_{2}}}$ - the values of the first and the second

The boundary value of the $\lambda$ test, which depends on the confidence level, was calculated using the formula [4]:

$$
\lambda=\sqrt{\frac{1}{2} \ln \frac{2}{p}}
$$

where: $p$ - the corresponding confidence level - 0.95; 0.99;

\begin{tabular}{|c|c|c|c|c|c|c|c|c|c|c|c|}
\hline Composition & Part of the stand & 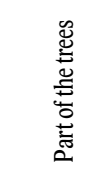 & 总怘 & 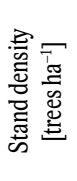 & 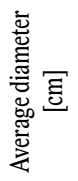 & 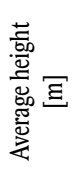 & 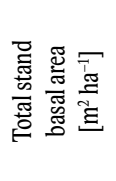 & 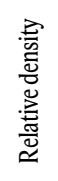 & 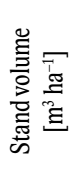 & 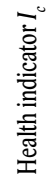 & $\lambda$ \\
\hline \multirow{4}{*}{$10 \mathrm{Sp}$} & & living & \multirow{4}{*}{51} & 770 & 20.5 & 18.5 & 25.47 & 0.59 & 220.1 & 20 & \multirow{4}{*}{4.62} \\
\hline & Disease center & dead & & 50 & 18.2 & 17.9 & 1.3 & 0.03 & 10.8 & 2.0 & \\
\hline & \multirow{2}{*}{ Control } & living & & 1185 & 18.2 & 17.8 & 30.98 & 0.74 & 260.5 & \multirow{2}{*}{1.6} & \\
\hline & & dead & & 21 & 10.1 & 13.7 & 0.17 & 0 & 1.1 & & \\
\hline \multirow{4}{*}{$10 \mathrm{Sp}$} & & living & \multirow{4}{*}{61} & 458 & 27.7 & 24.6 & 27.43 & 0.58 & 306.8 & & \multirow{4}{*}{5.37} \\
\hline & Disease center & dead & & 132 & 25.3 & 24.1 & 6.56 & 0.14 & 72.1 & 2.3 & \\
\hline & \multirow{2}{*}{ Control } & living & & 799 & 27.0 & 26.0 & 45.75 & 0.97 & 541.3 & \multirow[b]{2}{*}{1.6} & \\
\hline & & dead & & 73 & 18.6 & 22.6 & 1.99 & 0.04 & 20.8 & & \\
\hline \multirow{4}{*}{$10 \mathrm{Sp}$} & \multirow{2}{*}{ Disease center } & living & \multirow{4}{*}{75} & 167 & 37.6 & 25.8 & 18.61 & 0.39 & 228.9 & \multirow{2}{*}{2.9} & \multirow{4}{*}{6.86} \\
\hline & & dead & & 80 & 34.6 & 25.0 & 7.52 & 0.16 & 85.5 & & \\
\hline & \multirow{2}{*}{ Control } & living & & 491 & 35.0 & 26.3 & 46.91 & 0.98 & 561.4 & \multirow[b]{2}{*}{1.3} & \\
\hline & & dead & & 5 & 22.6 & 22.0 & 0.2 & 0 & 2.1 & & \\
\hline \multirow{4}{*}{ 9Sb } & \multirow{4}{*}{ Whole stand } & living & \multirow{4}{*}{51} & 724 & 20.2 & 22.0 & 23.04 & 0.76 & 234.5 & 1.5 & \multirow{4}{*}{-} \\
\hline & & dead & & 21 & 15.6 & 19.6 & 0.39 & 0.01 & 3.5 & & \\
\hline & & living & & 76 & 20.5 & 22.1 & 2.52 & 0.06 & 25.7 & 1.5 & \\
\hline & & dead & & - & - & - & - & - & - & - & \\
\hline
\end{tabular}
0.999 .

Table 1. Mensurational indices for pine plantations in the root rot disease centers and in the control (the area between the disease centers) and for birch plantations in fresh oak-pine fairly infertile site type.

Notes: $\mathrm{Sp}$-Scots pine; $\mathrm{Sb}$ - silver birch. 
The boundary values of the $\lambda$ test are $1.36,1.63$ and 1.95 , respectively.

During the study, mensurational characteristics of the stands were obtained in the established sample plots, where the research on merchantability and assortment structure and the monetary valuation of trunk timber volumes were made (Table 1 ).

\section{Results}

The analysis of $\lambda$ value indicates that the compared populations of the trunk distribution by DBH categories, depending on the average diameter of the stand in the disease center and in the control, belong to different general populations and are described by different curves $(\lambda=4.62 \ldots 6.86>1.95)$, that is, the probability of differences exceeds $99 \%$ level (Table 2 ).

Wood losses by the total volume due to dying of trees caused by the disease increase considerably with aging. In artificial pine plantations of the age class VI, growing in the same forest site conditions, the total volume of trunk timber in the root rot disease centers is $7 \%$ less in comparison with the stand growing in the area between the disease centers; in the stands of the age classes VII and VIII, it is $39 \%$ and $57 \%$ less, respectively (Table 2). In total, in the 51-year-old pine stand, annosum root rot did not cause serious damage. In addition, the average diameter of this stand is $11 \%$ and the average height is $4 \%$ higher in the disease center than in the control.

As the age increases, the yield of the timber increased in both parts of the investigated stands: from $74 \%$ to $83 \%$ in the area between disease centers and from $74 \%$ to $78 \%$ in the disease centers. However, in the last, the yield of industrial raw materials decreases from $8 \%$ to $6 \%$ and of fuelwood, from $9 \%$ to $7 \%$. In the areas between annosum root rot centers, the decrease is from $7 \%$ to $3 \%$ and from $9 \%$ to $5 \%$, respectively. This difference is not significant.
In the 61-year-old pine stand, unlike other investigated stands, the yield of the timber is the maximum both in the centers of the disease (84\%) and in the areas between the centers (82\%), and the yield of industrial raw materials is almost the same (only $1 \%$ and $2 \%$, respectively). This is due to the selective sanitary felling carried out in this stand a year before the laying out sample plots.

The birch-pine stand differs from other investigated stands by a considerably smaller proportion of timber $59 \%$ only-and, respectively, a larger proportion of industrial raw materials (18\%) and fuelwood (15\%).

The medium-sized timber is prevalent in the pine plantations of the age classes VI - VII and in the birchpine plantations; in the pine stands of age class VII, the large-sized timber does (Fig. 3).

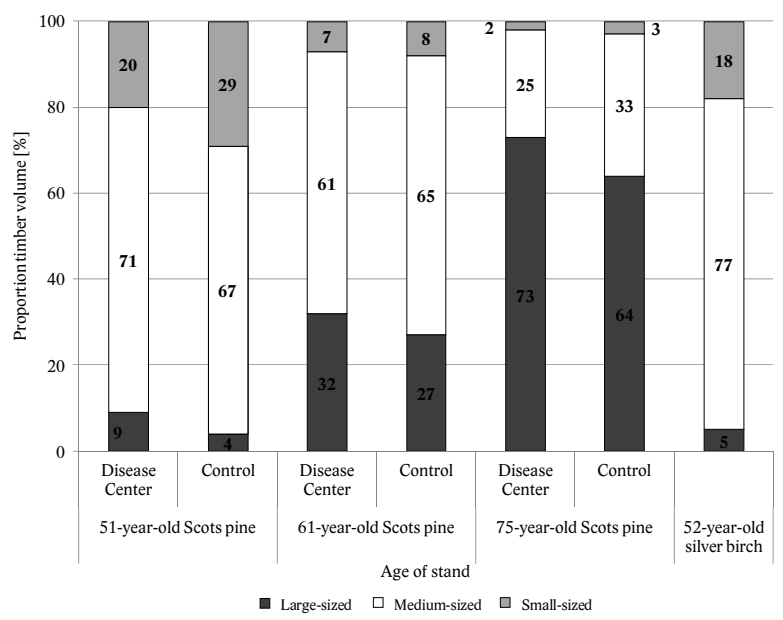

Fig. 3. Distribution of timber volume of pine and birch-pine forest plantations by size category.

As the age of pine plantations increases, the proportions of medium and small-sized timber decrease both in the disease centers (from 71 to $25 \%$ and from 20 to $2 \%$, respectively) and in the parts of the stand between

Table 2. Merchantability and assortment structure of the investigated stands.

\begin{tabular}{|c|c|c|c|c|c|c|c|c|c|c|c|c|c|c|c|c|c|}
\hline \multirow[b]{3}{*}{ 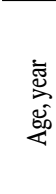 } & \multirow{3}{*}{ 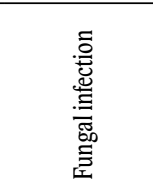 } & \multirow[b]{3}{*}{ 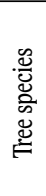 } & \multirow[b]{3}{*}{ 蒙 } & \multicolumn{9}{|c|}{ Timber } & \multicolumn{2}{|c|}{ Low-grade wood } & \multirow{3}{*}{ 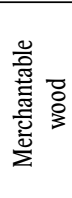 } & \multirow[b]{3}{*}{ 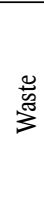 } & \multirow[b]{3}{*}{ 点 } \\
\hline & & & & & Size & & Timb & er dis & oution & asso & ents & & & & & & \\
\hline & & & & 总 & 志 & 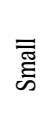 & 兰㐫 & $\frac{0}{3}$ & 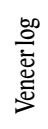 & 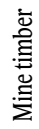 & $\begin{array}{l}\overline{0} \\
0 \\
\vdots \\
\vdots \\
\vdots\end{array}$ & 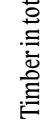 & 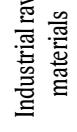 & 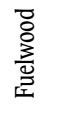 & & & \\
\hline \multirow{4}{*}{51} & \multirow{2}{*}{ Disease center } & \multirow{2}{*}{ Sp } & $\mathrm{m}^{3} \mathrm{ha}^{-1}$ & 15 & 122 & 34 & 102 & 21 & - & 33 & 14 & 170 & 18 & 20 & 208 & 22 & 230 \\
\hline & & & $\%$ & 6 & 53 & 15 & 44 & 9 & - & 14 & 6 & 74 & 8 & 9 & 91 & 10 & 100 \\
\hline & \multirow{2}{*}{ Control } & \multirow{2}{*}{ Sp } & $\mathrm{m}^{3} \mathrm{ha}^{-1}$ & 7 & 124 & 53 & 103 & 15 & - & 49 & 17 & 184 & 18 & 21 & 223 & 25 & 248 \\
\hline & & & $\%$ & 3 & 50 & 21 & 41 & 6 & - & 20 & 7 & 74 & 7 & 9 & 90 & 10 & 100 \\
\hline \multirow{4}{*}{61} & \multirow{2}{*}{ Disease center } & \multirow{2}{*}{ Sp } & $\mathrm{m}^{3} \mathrm{ha}^{-1}$ & 85 & 166 & 20 & 152 & 88 & - & 19 & 12 & 271 & 4 & 16 & 291 & 33 & 324 \\
\hline & & & $\%$ & 26 & 52 & 6 & 47 & 27 & - & 6 & 4 & 84 & 1 & 5 & 90 & 10 & 100 \\
\hline & \multirow{2}{*}{ Control } & \multirow{2}{*}{ Sp } & $\mathrm{m}^{3} \mathrm{ha}^{-1}$ & 116 & 283 & 36 & 251 & 126 & - & 36 & 22 & 435 & 12 & 28 & 475 & 53 & 528 \\
\hline & & & $\%$ & 22 & 53 & 7 & 47 & 24 & - & 7 & 4 & 82 & 2 & 6 & 90 & 10 & 100 \\
\hline \multirow{4}{*}{75} & \multirow{2}{*}{ Disease center } & \multirow{2}{*}{ Sp } & $\mathrm{m}^{3} \mathrm{ha}^{-1}$ & 140 & 49 & 4 & 60 & 126 & - & 3 & 4 & 193 & 15 & 17 & 225 & 22 & 247 \\
\hline & & & $\%$ & 56 & 20 & 2 & 24 & 51 & - & 1 & 2 & 78 & 6 & 7 & 91 & 9 & 100 \\
\hline & \multirow{2}{*}{ Control } & \multirow{2}{*}{ Sp } & $\mathrm{m}^{3} \mathrm{ha}^{-1}$ & 307 & 157 & 13 & 172 & 280 & - & 12 & 13 & 477 & 15 & 29 & 521 & 55 & 576 \\
\hline & & & $\%$ & 54 & 27 & 2 & 30 & 49 & - & 2 & 2 & 83 & 3 & 5 & 91 & 9 & 100 \\
\hline \multirow{6}{*}{51} & \multirow{6}{*}{ Whole stand } & \multirow{2}{*}{ Sp } & $\mathrm{m}^{3} \mathrm{ha}^{-1}$ & - & 16 & 4 & 13 & 1 & - & 4 & 2 & 20 & 3 & 3 & 26 & 3 & 29 \\
\hline & & & $\%$ & - & 55 & 14 & 45 & 3 & - & 14 & 7 & 69 & 10 & 10 & 89 & 11 & 100 \\
\hline & & \multirow[b]{2}{*}{$\mathrm{Sb}$} & $\mathrm{m}^{3} \mathrm{ha}^{-1}$ & 7 & 97 & 22 & 22 & 14 & 80 & - & 10 & 126 & 41 & 34 & 201 & 16 & 217 \\
\hline & & & $\%$ & 3 & 45 & 10 & 10 & 6 & 37 & - & 5 & 58 & 19 & 16 & 93 & 7 & 100 \\
\hline & & \multirow[b]{2}{*}{$\Sigma$} & $\mathrm{m}^{3} \mathrm{ha}^{-1}$ & 7 & 113 & 26 & 35 & 15 & 80 & 4 & 12 & 146 & 44 & 37 & 227 & 19 & 246 \\
\hline & & & $\%$ & 3 & 46 & 10 & 14 & 6 & 32 & 2 & 5 & 59 & 18 & 15 & 92 & 8 & 100 \\
\hline
\end{tabular}

Notes: $\mathrm{Sp}$ - Scots pine; $\mathrm{Sb}$ - silver birch. 
the centers (from 67 to $33 \%$ and from 29 to $3 \%$, respectively). Instead, the portion of large-sized timber grows significantly: from $9 \%$ to $73 \%$ in the disease centers and from $4 \%$ to $64 \%$ in the areas between the centers.

Merchantability structure of birch-pine plantations is dominated by the medium-sized timber (77\%). The proportion of small-sized timber is $18 \%$, and large, $5 \%$ only. However, the merchantability and assortment structure of such plantations can be significantly improved, assuming that intermediate felling is timely. In pine plantations, both in the disease centers and in the areas between the disease centers, the proportion of saw logs increases with aging - from 12 to $65 \%$ and from 8 to $59 \%$, respectively. The yield of small-sized wood assortments decreases: for the mine timber, from 19 to $2 \%$ and from 27 to $2 \%$, respectively, and for the building timber, from 60 to $31 \%$ and from 56 to $36 \%$, respectively. In birch-pine plantations, veneer logs and building timber prevail among assortments, which account for $55 \%$ and $24 \%$, respectively. The share of saw logs is only $10 \%$ of the timber volume. The value of the pine stand volume in the disease centers is reduced due to the negative impact of the root rot and is much smaller compared to that for the part of stand between the centers (Table 3 ).
The difference between the values of pine stand volume in the centers of forest decline and in the sites between the centers increases with age. It is $1 \%$ in the stand of age class VI, $36 \%$ in the stand of the age class VII and amounts to $57 \%$ in the VIII age class forest stand in favor of the healthy part of the stands (Table 4). In absolute terms, the difference in the volume values for affected and healthy parts of the stands increases with aging - from 40.7 EUR in the stands of the age class VI to 9471.6 EUR in the stands of the age class VIII.

The main part of the value structure of all studied plantations is the timber, which is the most valuable. With the aging, the value of the timber of pine plantations grows both in absolute and in relative terms. The share of the timber value increases from 90 to $95 \%$ in the centers of annosum root rot disease and from 90 to $97 \%$ in the part of the stands between the centers.

The proportion of the timber value in birch-pine plantations (83\%) is lower than that in artificial pine plantations of the appropriate age, while the parts of industrial raw materials and fuelwood ( $9 \%$ and $8 \%$, respectively), on the contrary, are higher (see Table 3).

Table 3. Monetary valuation of trunk timber volumes by 1 ha of pine and birch stands, EUR.

\begin{tabular}{|c|c|c|c|c|c|c|c|c|c|c|c|c|}
\hline \multirow[b]{3}{*}{ 总密 } & \multirow[b]{3}{*}{ 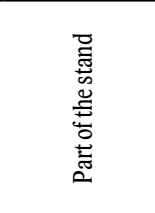 } & \multirow[b]{3}{*}{$\begin{array}{l}\frac{\mathscr{U}}{\tilde{U}} \\
\ddot{\tilde{w}}\end{array}$} & \multirow[b]{3}{*}{ 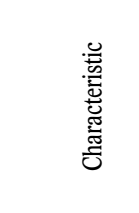 } & \multicolumn{6}{|c|}{ Timber } & \multirow[b]{3}{*}{ 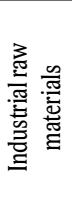 } & \multirow[b]{3}{*}{ 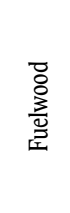 } & \multirow[b]{3}{*}{ 퓽 } \\
\hline & & & & \multicolumn{5}{|c|}{ Assortments } & \multirow[b]{2}{*}{ 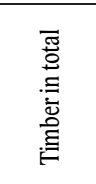 } & & & \\
\hline & & & & 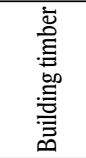 & 㤎 & 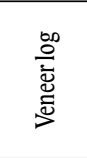 & 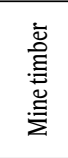 & 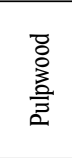 & & & & \\
\hline \multirow{6}{*}{51} & \multirow{4}{*}{ Disease center } & \multirow{3}{*}{ Sp } & Volume $\left[\mathrm{m}^{3}\right]$ & 102 & 21 & - & 33 & 14 & 170 & 18 & 20 & 208 \\
\hline & & & Cost [EUR] & 24.8 & 41.2 & - & 13.5 & 12.5 & - & 12.8 & 9.6 & - \\
\hline & & & Value [EUR] & 2529.6 & 865.2 & & 445.5 & 175.0 & 4015.3 & 230.4 & 192.0 & 4437.7 \\
\hline & & \multirow{3}{*}{ Sp } & Volume $\left[\mathrm{m}^{3}\right]$ & 103 & 15 & - & 49 & 17 & 184 & 18 & 21 & 223 \\
\hline & \multirow[t]{2}{*}{ Control } & & Cost [EUR] & 24.8 & 41.2 & - & 13.5 & 12.5 & & 12.8 & 9.6 & - \\
\hline & & & Value [EUR] & 2554.4 & 618.0 & & 661.5 & 212.5 & 4046.4 & 230.4 & 201.6 & 4478.4 \\
\hline \multirow{6}{*}{61} & \multirow{3}{*}{ Disease center } & \multirow{3}{*}{$\mathrm{Sp}$} & Volume $\left[\mathrm{m}^{3}\right]$ & 152 & 88 & - & 19 & 12 & 271 & 4 & 16 & 291 \\
\hline & & & Cost [EUR] & 24.8 & 41.2 & - & 13.5 & 12.5 & - & 12.8 & 9.6 & - \\
\hline & & & Value [EUR] & 3769.6 & 3625.6 & & 256.5 & 150.0 & 7801.7 & 51.2 & 153.6 & 8006.5 \\
\hline & \multirow{3}{*}{ Control } & \multirow{3}{*}{ Sp } & Volume $\left[\mathrm{m}^{3}\right]$ & 251 & 126 & - & 36 & 22 & 435 & 12 & 28 & 475 \\
\hline & & & Cost [EUR] & 24.8 & 41.2 & - & 13.5 & 12.5 & - & 12.8 & 9.6 & - \\
\hline & & & Value [EUR] & 6224.8 & 5191.2 & - & 486.0 & 275.0 & 12177.0 & 153.6 & 268.8 & 12599.4 \\
\hline \multirow{6}{*}{75} & \multirow{3}{*}{ Disease center } & \multirow{3}{*}{ Sp } & Volume $\left[\mathrm{m}^{3}\right]$ & 60 & 126 & - & 3 & 4 & 193 & 15 & 17 & 225 \\
\hline & & & Cost [EUR] & 24.8 & 41.2 & - & 13.5 & 12.5 & - & 12.8 & 9.6 & - \\
\hline & & & Value [EUR] & 1488.0 & 5191.2 & - & 40.5 & 50.0 & 6769.7 & 192.0 & 163.2 & 7124.9 \\
\hline & \multirow{3}{*}{ Control } & \multirow{3}{*}{ Sp } & Volume $\left[\mathrm{m}^{3}\right]$ & 172 & 280 & - & 12 & 13 & 477 & 15 & 29 & 521 \\
\hline & & & Cost [EUR] & 24.8 & 41.2 & - & 13.5 & 12.5 & - & 12.80 & 9.6 & - \\
\hline & & & Value [EUR] & 4265.6 & 11536.0 & & 162.0 & 162.5 & 16126.1 & 192.0 & 278.4 & 16596.5 \\
\hline \multirow{7}{*}{51} & \multirow{7}{*}{ Whole stand } & \multirow{3}{*}{$\mathrm{Sb}$} & Volume $\left[\mathrm{m}^{3}\right]$ & 22 & 14 & 80 & - & 10 & 126 & 41 & 34 & 201 \\
\hline & & & Cost [EUR] & 25.4 & 29.8 & 31.2 & - & 11.6 & - & 10.0 & 10.3 & - \\
\hline & & & Value [EUR] & 558.8 & 417.2 & 2496.0 & - & 116.0 & 3588.0 & 410.0 & 350.2 & 4348.2 \\
\hline & & \multirow{3}{*}{$\mathrm{Sp}$} & Volume $\left[\mathrm{m}^{3}\right]$ & 13 & 1 & - & 4 & 2 & 20 & 3 & 3 & 26 \\
\hline & & & Cost[EUR] & 24.8 & 41.2 & - & 13.5 & 12.5 & - & 12.8 & 9.6 & - \\
\hline & & & Value [EUR] & 322.4 & 41.2 & - & 54.0 & 25.0 & 442.6 & 38.4 & 28.8 & 509.8 \\
\hline & & $\Sigma$ & Value [EUR] & 881.2 & 458.4 & 2496.0 & 54.0 & 141.0 & 4030.6 & 448.4 & 379.0 & 4858.0 \\
\hline
\end{tabular}

Notes: $\mathrm{Sp}$ - Scots pine; $\mathrm{Sb}$ - silver birch.

Table 4. Comparison of the values of pine stands volumes in the disease centers and the control (areas between the disease centers) in euro.

\begin{tabular}{|c|c|c|c|c|c|c|c|c|c|}
\hline \multirow{3}{*}{ Commercial grade } & \multicolumn{9}{|c|}{ Age [years] } \\
\hline & \multicolumn{3}{|c|}{51} & \multicolumn{3}{|c|}{61} & \multicolumn{3}{|c|}{75} \\
\hline & Disease center & Control & Difference & Disease center & Control & Difference & Disease center & Control & Difference \\
\hline Timber & 4015.3 & 4046.4 & 31.1 & 7801.7 & 12177.0 & 4375.3 & 6769.7 & 16126.1 & 9356.4 \\
\hline Industrial raw materials & 230.4 & 230.4 & - & 51.2 & 153.6 & 102.4 & 192.0 & 192.0 & - \\
\hline Fuelwood & 192.0 & 201.6 & 9.6 & 153.6 & 268.8 & 115.2 & 163.2 & 278.4 & 115.2 \\
\hline Total & 4437.7 & 4478.4 & 40.7 & 8006.5 & 12599.4 & 4592.9 & 7124.9 & 16596.5 & 9471.6 \\
\hline
\end{tabular}


In artificial pine plantations, the total value of merchantable wood in the part of stands in the areas between root rot disease centers is $42 \%$ higher compared with that in the disease centers. For the period from VI to VII age class, the value of merchantable wood of the first generation pine plantations increases in 1.6 - 1.8 times in the disease centers and in 3.7 times in the control.

\section{Discussion}

Our results suggest a significant influence of annosum root rot on absolute and relative indicators of assortments yield and value of pine stands. These findings comply with the results of the other studies. For example, Lapitan et al. (2013) who conducted research in the neighboring region, Novgorod-Siverske Polissya, noted that in maturing and mature pine stands, the stock volume had decreased by an average of $24 \%$ and $33 \%$, respectively, in the centers of the disease. Our data show, however, that in Volyn Polissya, the total yield and the value of merchantable wood in the disease centers of artificial pine plantations affected by the root rot are even less, by $42 \%$ as compared with the part of the stands between the disease centers. All researchers agree that this negatively affected the distribution of assortments yield. Thus, Lapitan et al. (2013) indicate that in the disease centers, the yield of saw logs had decreased, on average, by $41 \%$ in maturing pine stands and by $50 \%$ in mature ones compared with that in sites between the disease centers. Instead, fuelwood yield had increased by $44 \%$ and $38 \%$, respectively. In general, losses from annosum root rot damage are $40 \%$ of the total value of the wood in maturing stands and $49 \%$ in the mature ones. According to our study in maturing stands in the Volyn Polissya zone, this indicator is similar to that obtained by Lapitan et al. (2013) and makes 42\%. The studies conducted in Eastern Polissya of Ukraine (Vedmid et al. 2013) testify that the growing stock and timber value of pine stands decrease even more, by $1.5-2$ times, in the root rot centers in comparison with that in the part of the stand between the centers.

According to Vedmid et al. (2013), birch stands have a better health condition as compared with the pine plantations in the declined sites, but the value of the "realizable" volume of their trunk timber is $1.2-1.9$ times less. At the same time, the authors note that the practicability of growing first-generation birch plantations in the formerly arable lands could be justified in the relation of forestry and biology as a preventive measure to create the preconditions for the further development of indigenous pine forest stands. Our results in Volyn Polissya indicate the higher value of merchantable wood of the middleaged (51 years old) birch-pine plantations as compared with pine stands of the same age: by $9 \%$ in the disease centers and by $8 \%$ in the areas between the disease centers (see Table 3). This is due to the high value of birch veneer log, which is the main product getting during the birch stands cultivation, while the proportion of saw logs in pine stands of the age class VI is small.

Since birch plantations are almost not established at the enterprise "Gorodotske Forest Economy", a comparative analysis of merchantability and assortment structure of artificial plantations for other age classes is not possible. Comparison of the merchantable structure of pine plantations with natural birch stands, the area of which at the enterprise is $6 \%$, is incorrect.

Consequently, all researchers agree that annosum root rot essentially affects the state, productivity, merchantability, and assortment structure of pine stands.

Thus, analysis and synthesis of the results obtained allow recommending the creation and cultivation of birch-pine plantations in Polissya on cutting areas after pine stands affected by annosum root rot. These plantations have the higher productivity and value of merchantable wood as compared with pure pine plantations of the appropriate age. Provided that the intermediate felling is done in a timely way, the productivity of the mixed birchpine plantations and, consequently, the economic efficiency of their cultivation can be improved greatly. Creation of pure pine plantations on the cutting areas after pine stands affected by annosum root rot is inadvisable, since there is a danger of re-infection of the tree stands (Ladeyshchikova et al. 2001, Mikhailichenko et al. 2014).

\section{Conclusion}

Annosum root rot negatively affects the productivity, merchantability and assortment structure of artificial pine stands of Volyn Polissya. The total yield and the value of merchantable wood of artificial pine plantations affected by annosum root rot are $42 \%$ less in the disease centers than that in the areas between the disease centers. The value of merchantable wood volume is higher on average by $8.5 \%$ in the middle-aged birch-pine plantations than in pine stands of the appropriate age affected by the disease. In Volyn Polissya, it is useful to establish and grow birch-pine plantations on the cutting areas after pine plantations affected by annosum root rot.

\section{References}

Anuchin, N. P., 1982: Forest Mensuration. Moscow, Lesnaya Promyshlennost, 552 p. [in Russian].

Bazzigher, G., Schmid, P., 1969: Sturmschaden und Faule. Schweizerische Zeitschrift fur Forstwesen, 10:521-535.

Bendz-Hellgren, M., Brandtberg, P.-O., Johansson, M., Swedjemark, G., Stenlid, J., 1999: Growth rate of Heterobasidion annosum in Picea abies established on forest land and arable land. Scandinavian Journal of Forest Research, 14:402-407. 
Brandtberg, P.-O., Johansson, M., Seeger, P., 1996: Effects of season and urea treatment on infection of stumps of Picea abies by Heterobasidion annosum in stands on former arable land. Scandinavian Journal of Forest Research, 11:261-268.

Churakov, B.P., Maslov, V.D., Churakov, R.A., 2013:The influence of root rot on pine wood products in focus of the disease. Vestnik of Ulyanovsk state agricultural academy, 4:59-66 [in Russian].

CMI, 1980. Distribution Maps of Plant Diseases, No. 271, edition 3. Wallingford, UK: CAB International.

EPPO, 2014. PQR database. Paris, France: European and Mediterranean Plant Protection Organization.

Froelich, R. C., Hodges, C. S., Sackett, S. S., 1978: Prescribed burning reduces severity of annosus root rot in the South. Forest Science, 24:93-100.

Harrington, T. C., Worrall, J. J., Rizzo, D. M., 1989: Compatibility among host-specialized isolates of Heterobasidion annosum from western North America. Phytopathology, 79:290-296.

Jambunathan, R., Butler, L. G., Bandyopadhyay, R., Mughogho, L. K., 1986: Polyphenol concentrations in grain, leaf, and callus tissues of mold-susceptible and mold-resistant sorghum cultivars. Journal of Agricultural and Food Chemistry, 34:425-429.

Khun, B. M., Geisler, M., Bigler, L., Ringli, Ch. 2011: Flavonols accumulate asymmetrically and affect auxin transport anArabidopsis. Plant Physiol. 156:585-595.

Ladeyshchikova, O. I., Ustsky, I. M., Chernykh, O. H., Mokrytsky, V. O., Bersneva, L. O., 2001: A guide to protect pine plantations against root rot. URIFFM, Kharkiv, Ukraine, 28 p. [in Ukrainian].

Lapitan, O. V., Zhemchuzhin, V. Y., Melnik, T. I., 2013: Components of damage from the root fungus in ripening and mature pine plantations of NovgorodSeversk Polyssya. The SNAU Vestnik, 11:14-19 [in Ukrainian].

Marinich, A. M., Pashchenko, V. M., Shishchenko, P. G., 1985: The nature of the Ukrainian SSR. Landscapes and physiographic mapping. Kyiv, Naukova Dumka, 224 p. [in Russian].

Massey, Frank, J.,Jr., 1951:The Kolmogorov-SmirnovTest for Goodness of Fit. Journal of the American Statistical Association, 46:68-78.

Mihaylichenko, A. A., Ustsky, I. M., Vedmid, M. M., Lozitsky, V. G, 2014: Growth characteristics of pine stands affected by annosum root rot in NovgorodSiverske Polissya. Forestry and Forest Melioration 124:36-41 [in Ukrainian].

Negrutskiy, S. F., 1973: Root Rot. Moscow, Lesnaya Promyshlennost, 200 p. [in Russian].

Nikitin, K. E. (ed.), 1984: Assortment tables for mensuration of standing forest. Kyiv, Urozhay, 632 p. [in Russian].

Onyskiv, M. I., Kidyk, O. Ju., 2008: Results of 30-years studying of problem of Scotch pine plantations protection from root rot in Polesye. Forestry and Forest Melioration, 114:201-206 [in Ukrainian].
Parmasto, E., 1986: Preliminary list of Vietnamese Aphyllophorales and Polyporaceae s. str. Tan-lin, $88 \mathrm{p}$.

Pearse, P. H., 1990: Introduction to forestry economics. UBC Press, $226 \mathrm{p}$.

Räsänen, P. K., Pohtila, E., Laitinen E. et al., 1985: Metsien uudistaminen kuuden eteläisimmän piirimetsälautakunnan alueella. Vuosien 1978-1979 inventointitulokset. Folia Forestalia, 637:1-30.

Sanitary Forests Regulations in Ukraine, 2016: Kyiv, Cabinet of Ministers of Ukraine. Available at: http:// zakon5.rada.gov.ua/laws/show/555-95-\%D0\%BF [in Ukrainian].

Semenkova, I. G., 1971: Attack of spruce understorey by Heterobasidion annosum. Nauchnye trudy MLTI, 38:150-166 [in Russian].

Shvydenko, A. Z., Strochinsky, A. A., Savich, Yu. N., Kashpor, S. N. (eds.), 1987: Normative and reference materials for forest inventory in Ukraine and Moldova. Kyiv, Urozhay, 559 p. [in Russian].

Strochinsky, A. A., Kashpor, S. M., Berezivsky, L. M., 2007a: The total basal area and the stock volume of stands at stoking of 1.0. Forest Mensuration Standards. Kyiv, NAU Publishing House, 19 p. [in Ukrainian].

Strochinsky, A. A., Kashpor, S. M., Polyakov, O. V., 2007b: Models of dimensional and qualitative structure of the volume of trunks of the main forest forming species. Forest Mensuration Standards. Kyiv, NAU Publishing House, 14 p. [in Ukrainian].

Synyakevych, I. M., 1996: Economics of the forest sector. Lviv, Svit, 184 p. [in Ukrainian].

USDA Forest Service, 2003. Forest insect and disease conditions in the United States 2002. USDAForest Service, Forest Health Protection, June 2003, 136 p.

Vasiliauskas, R., Juska, E., Vasiliauskas, A., Stenlid, J., 2002: Community of Aphyllophorales and root rot in stumps of Picea abies on clear-felled forest sites in Lithuania. Scandinavian Journal of Forest Research, 17:398-407.

Vedmid, M. M., Tarnopilska, O. M., Kobets, O. V., Zuev, E. S., Lozitsky, V. G., 2013: State, productivity and assortment structure of first generation pine and birch stands cultivated on abandoned agricultural lands of East Polissya. Forestry and Forest Melioration, 122:12-23 [in Ukrainian].

Vollbrecht, G., Gemmel, P., Elfving, B., 1994: Forest management with the purpose of reducing windthrow and infection by Heterobasidion annosum in Picea abies - preliminary results from a field experiment. In: Vollbrecht, G.: Effects of silvicultural practices on the incidence of root and butt rot in Norway spruce with special emphasis on Heterobasidion annosum. Doctoral thesis, Swedish University of Agricultural Sciences, Alnarp, Sweden.

Yde-Andersen, A., 1970: Fomes annosus in conifer stands of first and second rotation. In: Hodges, C. S., Rishbeth, J., Yde-Andersen A. (eds): Proceedings of the $3^{\text {rd }}$ IUFRO Conference on Fomes annosus. (Denmark, July-August 1968). USDA, Washington DC, p. 137-148. 